\title{
Verification of new Populus nigra L. clone improvement based on their performance over three rotations
}

\author{
Kateřina Novotná, \\ Petra Štochlová, \\ Vojtěch Benetka
}

\begin{abstract}
Populus nigra is an important autochthonous woody plant that can be grown as a renewable energy source. The possibility of its improvement through intraspecific hybridization was tested. Differences in biomass production, growth parameters, Melampsora larici-populina rust resistance and drought tolerance were evaluated among 19 intraspecific hybrids from controlled crosses, 2 clones selected from natural populations and the "MAX 4" clone $(P$. nigra $\times P$. maximowiczii). These $P$. nigra clones from controlled crosses were chosen from more than 2000 hybrid individuals whose parents were selected from natural populations in the Czech Republic. A field trial was set up in Průhonice, Czech Republic $(320 \mathrm{~m}$ a.s.l., $591 \mathrm{~mm}$ rainfall annually, mean annual temperature of $9.5^{\circ} \mathrm{C}$ ). The planting density was 6061 plants ha $^{-1}$, and the plants were coppiced three times at 3-year intervals. The trial was irrigated only during its establishment. Among the clones, significant differences were found in all the evaluated traits over three rotations. An average dry matter yield of the best clone "MAX 4" was $12.8 \mathrm{t} \mathrm{ha}^{-1} \mathrm{yr}^{-1}$ over three harvests. The best black poplar clone reached up to $9.4 \mathrm{t} \mathrm{ha}^{-1} \mathrm{yr}^{-1}$ in three harvests. Rust resistance was constant over 9 years and high for the three $P$. nigra clones (two from controlled crosses and one from natural populations). Moreover, the best $P$. nigra clones from controlled crosses showed higher drought tolerance than the "MAX 4" clone. Breeding progress was confirmed, and most of the $P$. nigra clones from controlled crosses performed better than the clones selected from natural populations. The trial validated the suitability of natural populations for use as gene sources for intraspecific hybridization and as sources of clones with traits comparable with those of interspecific clones. These new $P$. nigra clones can replace allochthonous clones in areas where autochthonous $P$. nigra populations are threatened by introgression.
\end{abstract}

Keywords: Plant Breeding, Black Poplar, Intraspecific Hybridization, Short Rotation Coppice Culture, Melampsora larici-populina, Biomass Production, Tree Regeneration

\section{Introduction}

In recent years, the importance of fastgrowing trees cultivation intensively managed as coppices with 2- to 5-year rotation cycles and potential lifetimes of 30 years (DEFRA 2004), the so-called short-rotation coppice (SRC) cultures, has increased with the increasing demand for woody biomass as a renewable energy source (Bentsen \& Felby 2012). This trend is apparent in the Czech Republic, where the total SRC area has increased by more than eight times

within the last 8 years and is now at 2862 ha (Ministry of Agriculture of the Czech Republic 2018).

Similar to those in other European countries (Herve \& Ceulemans 1996, Verwijst 2001, Langeveld et al. 2012), Czech SRC cultures are usually based on poplar or willow species, and the most commonly grown poplars in Europe are primarily the result of interspecific crosses. In countries with the highest SRC area (France, Italy and Spain), the most popular parental combinations of

Silva Tarouca Research Institute for Landscape and Ornamental Gardening, Publ. Res. Inst., Květnové náměstí 391, CZ-252 43 Průhonice (Czech Republic)

@ Kateřina Novotná (novotna@vukoz.cz)

Received: Jun 19, 2019 - Accepted: Mar 14, 2020

Citation: Novotná K, Štochlová P, Benetka V (2020). Verification of new Populus nigra L. clone improvement based on their performance over three rotations. iForest 13: 185-193. doi: 10.3832/ifor3171-013 [online 2020-05-12]

these clones are Populus deltoides Marsh. $\times$ P. nigra L. (= P. $\times$ canadensis Moench), P. trichocarpa Torr. \& A. Gray $\times$ P. deltoides, P. nigra $\times$ P. maximowiczii Henry and $P$. maximowiczii $\times$ P. trichocarpa (FAO 2016); however, in central Europe, the trend in recent years has been to grow the "MAX 4" hybrid clone of $P$. nigra $\times P$. maximowiczii (Štícha et al. 2016). The popularity of F1 interspecific hybridization is due to the predominance of heterosis and the ease with which it can be economically exploited through vegetative propagation (Stanton et al. 2010).

$P$. nigra is an autochthonous woody plant that covers a large area of Europe (Vanden Broeck 2003), and its populations can be threatened by introgression from the aforementioned interspecific hybrid clones and other clones of allochthonous poplar species (Smulders et al. 2008). The relevant causes are cultivated poplar trees grown to the adult stage, which is the case not only for clones coming from $P$. deltoides and $P$. trichocarpa but also for interspecific hybrids of $P$. $\times$ canadensis-type that can spontaneously interbreed with $P$. nigra (Benetka 
et al. 2002b). The contamination of P. nigra gene pools has led to restrictions on interspecific hybrid cultivation in certain locations (Ministry of the Environment of the Czech Republic 1992).

The original autochthonous species $P$. nigra is not commonly grown in its pure form, and few cultivars are available. Furthermore, these clones are usually selected from natural populations (IPC 2000). According to previously published studies (Nielsen et al. 2014, Verlinden et al. 2015), $P$. nigra clones are the least productive, although certain clones derived from genetically pure $P$. nigra produce yields comparable to or exceeding those of interspecific hybrid clones (Benetka et al. 2002a, Al Afas et al. 2008, Dillen et al. 2013). Additionally, pure $P$. nigra clones are not commonly grown because of their generally reported susceptibility to leaf rust caused by Melampsora larici-populina Kleb., which is the case in Western Europe (Steenackers 1972).

M. larici-populina leaf rust is one of the main diseases of cultivated poplars and can cause severe damage and economic losses (Frey et al. 2005). This disease negatively affects biomass production (Gastine et al. 2003, Benetka et al. 2012, Štochlová et al. 2015), resulting in yield losses of up to $66 \%$ in P. nigra clones (Štochlová et al. 2015). The resistance of $P$. nigra to $M$. larici-populina shows a quantitative inheritance (Dowkiw et al. 2012), as demonstrated by a genetic analysis of this trait (Benetka et al. 2005). This type of resistance does not ensure complete resistance but produces more durability than qualitative resistance. In contrast, the qualitative resistance that occurs in some $P$. deltoides clones ensures complete or near-complete resistance to some M. larici-populina strains (Pinon 1992, Dowkiw \& Bastien 2004), although this resistance can be suddenly overcome (Dowkiw et al. 2012). Due to the transitory nature of resistance based on qualitative resistance genes, plant breeders now focus their efforts on quantitative resistance genes, for which selection is slower but the risk of a sudden loss of resistance is reduced (McDonald 2010).

Another goal in poplar breeding has arisen with the projected dryer summer climate in Central-Western Europe (Schär et al. 2004, Seneviratne et al. 2006, Kreuzwieser \& Gessler 2010). Poplars are especially sensitive to water deficiency and could be threatened by these climatic extremes. The growth of their leaves and shoots is affected by water shortage (Monclus et al. 2009), affecting the total biomass, leaf area, shoot height and diameter (Monclus et al. 2006). Therefore, these traits are used as indicators of drought, and their evaluation can be used to select genotypes with higher drought tolerance.

A prerequisite for successful breeding for resistance to drought is variability in the traits observed in the genus Populus L.; namely, in P. nigra, variability was observed between populations originating from contrasting climatic conditions within Europe (Viger et al. 2016). There are consistent genotypic differences in the water-use efficiency (WUE) of poplar species and hybrids, along with a lack of correlation between the WUE and productivity of poplar clones (Marron et al. 2005, Monclus et al. 2005, 2006, Navarro et al. 2018). This indicates that there is the potential for the selection of poplar clones that combine high WUE and high productivity, which would be an advantage for the growth of poplar trees in moderately drought-prone areas (Braatne et al. 1992, Jones et al. 2016).

The black poplar clones used in studies by Benetka et al. (2002a, 2014) and Dillen et al. (2013) were derived from natural populations and did not represent the products of any type of selective breeding. Newly released clones arising from cross-pollination might be promising and have a potential

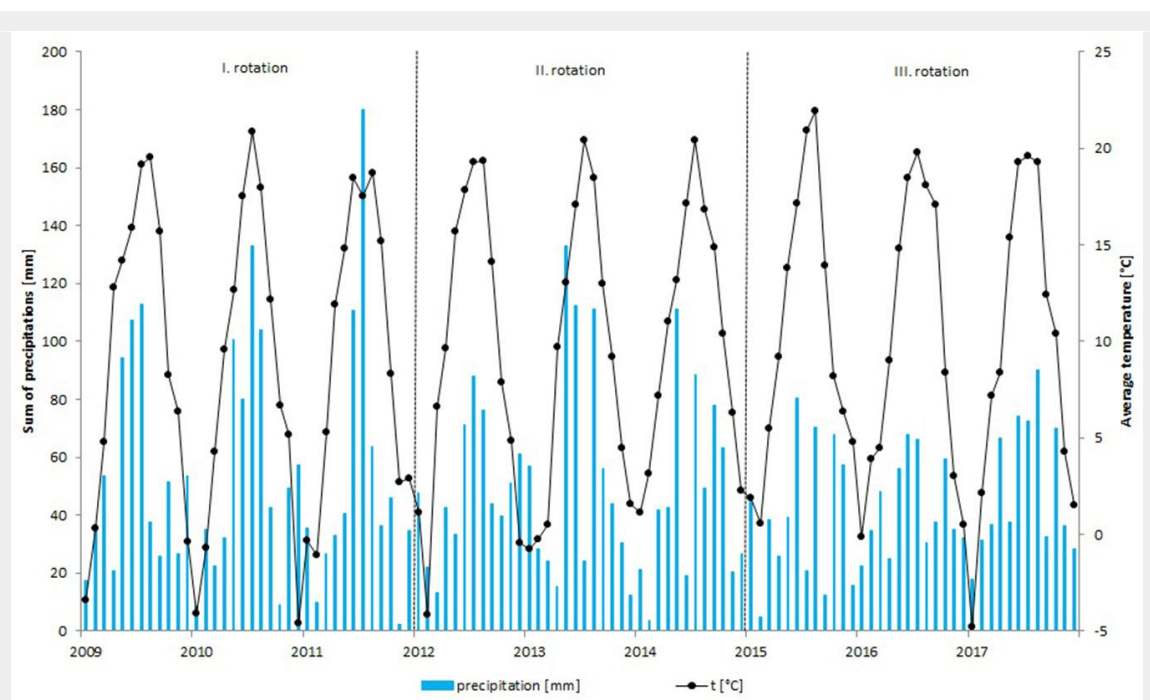

Fig. 1 - Monthly cumulative precipitation (blue bars) and average temperatures (black points) during the experimental period (2009-2017).

production value comparable to that of commercial hybrid poplar clones when parental clones originate from contrasting conditions (Benetka et al. 2012).

The aim of the present study was: (i) to verify whether black poplar clones originating from intraspecific hybridization (controlled crossings) of parental trees from local populations were improved in yield and growth traits and leave rust resistance in comparison with selected clones from natural populations; (ii) to verify whether their performance was comparable with that of commercial interspecific hybrid clones; and (iii) to choose black poplar clones that are convenient for growing in SRC systems under suboptimal conditions.

\section{Materials and methods}

\section{Materials}

Twenty-one clones of $P$. nigra L. ssp. nigra from the black poplar breeding programme of Silva Tarouca Research Institute for Landscape and Ornamental Gardening, Publ. Res. Inst. (Czech Republic), including 19 clones originating from 9 intraspecific hybrid combinations (Benetka et al. 2012), were used in a field trial. These clones were chosen among 2227 individuals for their good yield potential and high level of resistance to $M$. larici-populina leaf rust (Benetka et al. 2012). An additional, leaf rust-susceptible intraspecific clone (98/37) was only used to confirm rust infection and represented an additional rust source. The parental trees used in our crossings were plus trees selected from natural populations, and crosses were performed between parents from different climatic and geographic regions, with their genetic diversity previously confirmed by microsatellite DNA analysis (Benetka et al. 2012).

Two other P. nigra clones (202 and 301) selected from a set of approximately 200 plus trees originating from natural populations (Benetka et al. 2007) were chosen as reference clones based on long-term yield trials (Benetka et al. 2014) to evaluate the improvement in $\mathrm{P}$. nigra clones from controlled crosses. Furthermore, clone 202 is one of the parental trees of several tested $P$. nigra clones $(00 / 234,00 / 237,00 / 239$, and $00 / 274)$. In addition to these two clones, the "MAX 4" clone, an interspecific hybrid of $P$. nigra $\times P$. maximowiczii, was used as a reference clone.

\section{Locality and experimental design}

The trial was established at the Silva Tarouca Research Institute for Landscape and Ornamental Gardening in Průhonice, Czech Republic (Central Bohemia $-49^{\circ} 59^{\prime}$ $\left.26^{\prime \prime} \mathrm{N}, 14^{\circ} 34^{\prime} 40^{\prime \prime} \mathrm{E}\right)$ in spring 2009 (Benetka et al. 2012). The plantation site is in a flat location at an altitude of $320 \mathrm{~m}$ a.s.l. facing slightly towards the south, and it consists of arable land that was grassed over before the establishment of the plantation. The soil type is modal brown earth found on loess, and the ground water level 
is approximately $2.1 \mathrm{~m}$ deep. The location is a suitable but rather dry area with frequent drying winds. The trial was not fertilized and was irrigated only before the establishment of the plantation and at sapling planting, respectively. The monthly average temperatures and cumulative precipitation during the 2009-2017 experimental periods are shown in Fig. 1, and Lang's rain factor is shown in Fig. 2. The mean annual temperatures and mean annual cumulative precipitation were 9.0, 9.5 and $9.9{ }^{\circ} \mathrm{C}$ and 643.6 , 601.4 and $528.8 \mathrm{~mm}$ in first (2009-2011), second (2012-2014) and third (2015-2017) rotations, respectively.

One-year-old saplings, obtained by cultivating $0.2 \mathrm{~m}$-long hardwood cuttings, were cut at a height of $0.5 \mathrm{~m}$ and planted with a planting machine at a spacing of $3.0 \times 0.55$ $\mathrm{m}$ (i.e., a plant density of 6061 plants per ha) in spring 2009. A randomized block design with two to five (predominantly four) blocks for each $P$. nigra clone and eight blocks for the "MAX 4" reference clone was used, and four or five plants of each clone were included in each block. Border rows were planted around the experimental plot to prevent any border effect, and the plot was also fenced to prevent browsing by wild animals.

\section{Measurements}

Biomass was harvested three times, and these harvests were separated by a threeyear interval. Plants were coppiced in February 2012 for the first time, in January 2015 for the second time, and in February 2018 for the third time. Individual plants were cut by hand with a chainsaw at a height of approximately $0.1 \mathrm{~m}$ above the ground at the first harvest and at $\sim 0.05 \mathrm{~m}$ above the previous cut at the following harvests. During the harvests, the fresh woody aboveground biomass produced by all plants of a given clone in each block was pooled and weighed. To simultaneously estimate the dry weight yield, a representative sample of the harvested material (equally from 1-, 2- and 3-year-old part), including the main and lateral shoots, was collected from each block and weighed separately. The size of these samples ranged from 300 to $1000 \mathrm{~g}$ depending on the diameter of the shoots. The samples were dried at $105^{\circ} \mathrm{C}$ until their weights were constant, and the average dry matter weight of the individual plants (DMIP), expressed as kg $\mathrm{r}^{-1}$, was calculated from the weight of the harvested fresh biomass from a given block, multiplied by the appropriate value of the percent dry matter, and divided by the number of plants in a given block and by the length of the rotation. The total dry matter yield per unit area (ha) and the percentage of living plants were then calculated.

At the end of first rotation cycle before harvesting, the main shoot diameter was measured with a digital calliper at a height of $0.5 \mathrm{~m}$ above the ground. In the following rotation cycles before harvesting, all shoots thicker than $0.01 \mathrm{~m}$ at this height

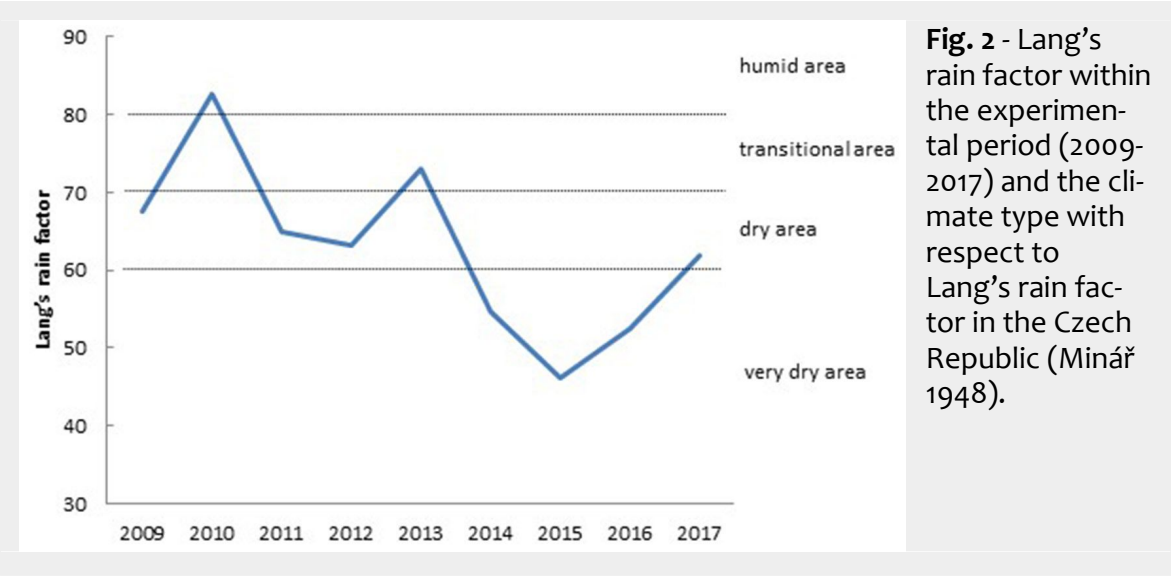

were counted and their diameters were measured. The shoot with the highest diameter in each plant was considered the main shoot. Before the second and third harvest, the combined total cross-sectional area (TCA) of all measured shoots was calculated and expressed as the sum of the per plant area in $\mathrm{mm}^{2}$. In the autumn before harvesting, plant mortality was determined as the percentage of dead plants relative to the total number of plants planted.

The incidence of $M$. larici-populina leaf rust was evaluated under field conditions, in a previous study (Štochlová et al. 2015) virulences 2, 3, 4, 5 and 7 were detected on test clones. Evaluations were made using a 6-point scale ranging from $0=$ no symptoms of rust infection on the leaves to $5=$ all leaves necrotized or shed (Štochlová et al. 2015) at least once during a vegetation period (April-September). The point values presented are the means of the point evaluations performed for each replication in mid-August, and the mean point value of

rust incidence was calculated based on an annual rust evaluation over a nine-year period.

\section{Statistical analysis}

Statistical evaluations were carried out using software R ( $R$ Core Team 2019) or Statistica $^{\oplus}$ v. 11.0 (StatSoft Inc., Tulsa, OK, USA). Clones (fixed factor) and blocks (random factor) were used as the independent variables, and the parameters of the number of shoots per plant, diameter of the main shoots, TCA, DMIP and dry matter yield per unit area were used as the dependent variables in linear mixed-effects model of ANOVA (Bates et al. 2015). The parameter mortality was not statistically evaluated due to its minimal variability. The square root transformation (Anděl 1998) was applied to the number of shoots per plant to obtain an approximately normally distributed variable. When a significant difference was found, a post hoc comparison was carried out using Tukey's test. The

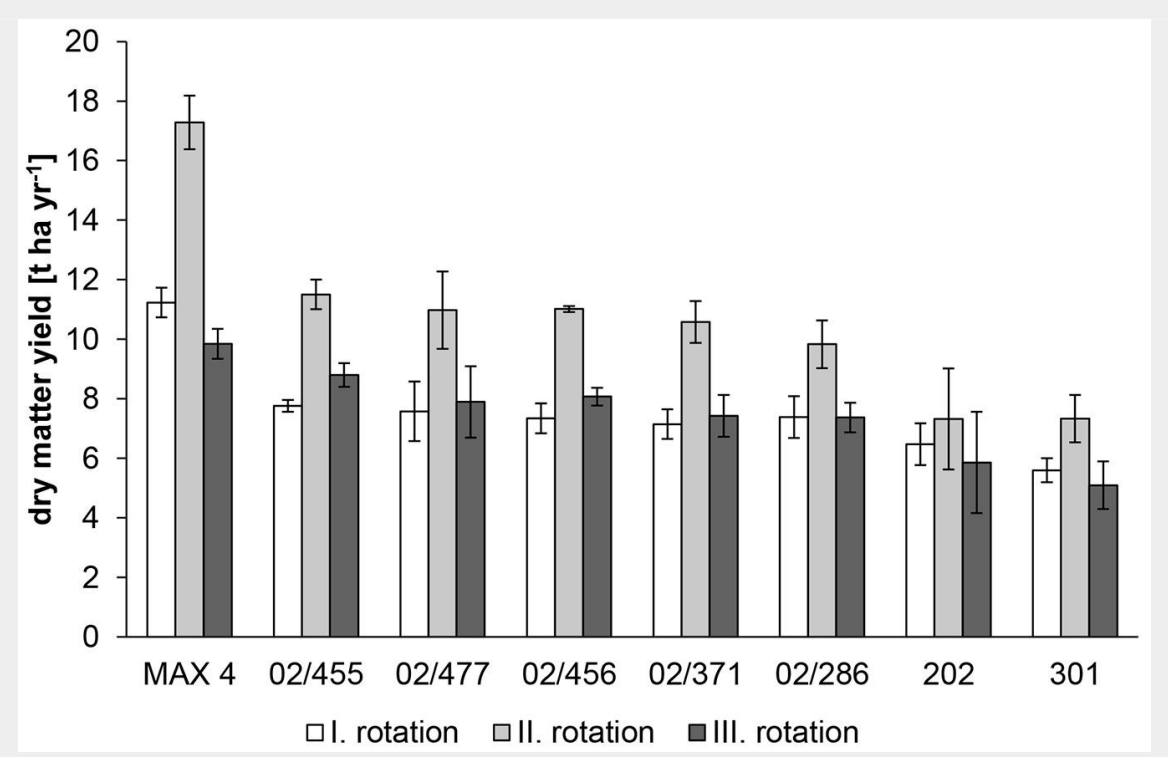

Fig. 3 - Mean value of the dry matter yield for the five best $P$. nigra clones from controlled crosses $(02 / 455,02 / 477,02 / 456,02 / 371,02 / 286), P$. nigra reference clones from natural populations $(202,301)$ and the $P$. nigra $\times P$. maximowiczii reference clone "MAX 4 " within the first (I.), second (II.) and third (III.) rotations. The bars represent the standard errors of the mean values. 
Tab. 1 - P-values of the linear mixed-effects model of ANOVA (effects of the clone or block on dependent variables) in the first (I.), second (II.) and third (III.) rotations. (TCA): total cross-sectional area; (DMIP): dry matter weights of individual plants.

\begin{tabular}{llll}
\hline Variable & Rotation & Block & Clone \\
\hline Diameter of strongest shoot & I. & $>0.5$ & $<0.001$ \\
\cline { 2 - 4 } & II. & 0.127 & $<0.001$ \\
\cline { 2 - 4 } Average shoot diameter & III. & 0.055 & $<0.001$ \\
\cline { 2 - 4 } & II. & $>0.5$ & $<0.001$ \\
\cline { 2 - 4 } Number of shoots per plant & III. & 0.104 & $<0.001$ \\
\cline { 2 - 4 } & II. & 0.4 & $<0.001$ \\
TCA & III. & 0.241 & $<0.001$ \\
\cline { 2 - 4 } DMIP & III. & 0.004 & $<0.001$ \\
& I. & 0.001 & $<0.001$ \\
\cline { 2 - 4 } & II. & $>0.5$ & $<0.001$ \\
\cline { 2 - 4 } Dry matter yield per unit area & III. & 0.5 & $<0.001$ \\
\cline { 2 - 4 } & I. & $>0.058$ & $<0.001$ \\
\cline { 2 - 4 } & II. & 0.5 & $<0.001$ \\
\cline { 2 - 4 } & III. & 0.086 & $<0.001$ \\
\hline
\end{tabular}

Kruskal-Wallis test was used for testing differences in the percentage variations between first and second and the second and third harvests. When a significant difference was found, a post hoc comparison was made using multiple comparisons of mean ranks. Significant differences in wood production between the rotations were established based on the results of $t$ tests, and Spearman's coefficient of rank correlation was calculated between the particular dates of rust incidence evaluations and between the TCA and DMIP in the second and third harvest. The relationship between the clones and rust incidence was tested using Pearson's coefficient of contingency. All results are presented using a significance level of $a<0.05$.

\section{Results}

\section{Biomass production}

The amount of biomass production was evaluated based on the results from all three harvests. The biomass production increased between the first and second harvests in all clones, and the increases were significant in nine of these clones (Fig. 3, Tab. S1 in Supplementary material). In contrast, biomass production decreased between the second and third harvest, and the decreases were significant for thirteen of these clones. The higher part of observed variability in yield was explained by the variable of clone. Significant clonal differences were found in every harvest (Tab. 1, Tab. S1 in Supplementary material).

The "MAX 4" clone displayed the highest DMIP in all rotations (Tab. S1 in Supplementary material), presenting mean values of $1.9,2.9$ and $1.6 \mathrm{~kg} \mathrm{yr}^{-1}$ in the first, second and third harvests, respectively. The DMIP of the $P$. nigra clones ranged from 0.9 to 1.3 $\mathrm{kg} \mathrm{yr}^{-1}$ in the first harvest, from 1.1 to $1.9 \mathrm{~kg}$ $\mathrm{yr}^{-1}$ in the second and from 0.8 to $1.5 \mathrm{~kg} \mathrm{yr}^{-1}$ in the third. Significant differences among the "MAX 4" clone and P. nigra clones were found in every harvest, but the DMIP of 5 intraspecific clones (02/455, 02/456, 02/477, 02/371, 02/476) did not differ significantly

Tab. 2 - Health status of the tested clones (mortality within the first (I.), second (II.) and third (III.) rotations and rust incidence within the trial observation period, 2009-2017). P. nigra $\times$ P. maximowiczii reference clone is "MAX 4", P. nigra reference clones from natural populations are 202 and 301, the rest clones are P. nigra clones from controlled crosses from which only clone $98 / 37$ is leaf rust susceptible. Values are means \pm standard error.

\begin{tabular}{|c|c|c|c|c|c|c|c|c|c|c|c|c|c|}
\hline \multirow{2}{*}{ Clone } & \multicolumn{3}{|c|}{ Mortality (\%) } & \multicolumn{3}{|c|}{ Rust incidence (points) } & \multirow[b]{2}{*}{2012} & \multirow[b]{2}{*}{2013} & \multirow[b]{2}{*}{2014} & \multirow[b]{2}{*}{2015} & \multirow[b]{2}{*}{2016} & \multirow[b]{2}{*}{2017} & \multirow[b]{2}{*}{ 2009-2017 } \\
\hline & I. & II. & III. & 2009 & 2010 & 2011 & & & & & & & \\
\hline MAX 4 & 0 & 0 & 0 & $0.1 \pm 0.0$ & $0.1 \pm 0.0$ & $0.2 \pm 0.1$ & $0.6 \pm 0.1$ & $0.2 \pm 0.1$ & $0.1 \pm 0.1$ & $0.9 \pm 0.1$ & $0.4 \pm 0.1$ & $0.8 \pm 0.1$ & $0.4 \pm 0.0$ \\
\hline $00 / 234$ & 0 & 0 & 0 & $0.1 \pm 0.0$ & $1.1 \pm 0.2$ & $1.6 \pm 0.1$ & $0.7 \pm 0.2$ & $0.5 \pm 0.0$ & $0.4 \pm 0.1$ & $0.3 \pm 0.2$ & $1.0 \pm 0.5$ & $1.0 \pm 0.0$ & $0.7 \pm 0.1$ \\
\hline $02 / 477$ & 0 & 0 & 0 & $0.1 \pm 0.0$ & $0.8 \pm 0.1$ & $2.3 \pm 0.3$ & $0.9 \pm 0.1$ & $1.0 \pm 0.2$ & $0.5 \pm 0.0$ & $0.9 \pm 0.1$ & $1.3 \pm 0.1$ & $1.0 \pm 0.0$ & $1.0 \pm 0.1$ \\
\hline 202 & 0 & 0 & 0 & $0.2 \pm 0.1$ & $1.8 \pm 0.3$ & $1.5 \pm 0.1$ & $0.8 \pm 0.3$ & $1.0 \pm 0.0$ & $0.5 \pm 0.0$ & $0.8 \pm 0.3$ & $1.3 \pm 0.3$ & $1.0 \pm 0.0$ & $1.0 \pm 0.1$ \\
\hline $00 / 441$ & 0 & 0 & 0 & $0.1 \pm 0.0$ & $1.3 \pm 0.1$ & $2.0 \pm 0.1$ & $0.5 \pm 0.0$ & $1.0 \pm 0.3$ & $0.5 \pm 0.0$ & $0.5 \pm 0.0$ & $1.6 \pm 0.1$ & $2.0 \pm 0.0$ & $1.1 \pm 0.1$ \\
\hline $00 / 237$ & 0 & 0 & 0 & $0.2 \pm 0.1$ & $1.8 \pm 0.2$ & $1.7 \pm 0.2$ & $1.3 \pm 0.3$ & $1.0 \pm 0.0$ & $0.5 \pm 0.0$ & $1.0 \pm 0.3$ & $0.8 \pm 0.2$ & $1.3 \pm 0.3$ & $1.1 \pm 0.1$ \\
\hline $02 / 21$ & 0 & 0 & 0 & $0.2 \pm 0.1$ & $1.4 \pm 0.1$ & $1.6 \pm 0.4$ & $0.6 \pm 0.1$ & $1.3 \pm 0.1$ & $0.5 \pm 0.0$ & $1.0 \pm 0.0$ & $1.5 \pm 0.0$ & $1.8 \pm 0.3$ & $1.1 \pm 0.1$ \\
\hline $00 / 239$ & 0 & 0 & 0 & $0.3 \pm 0.1$ & $1.9 \pm 0.1$ & $1.9 \pm 0.1$ & $0.9 \pm 0.1$ & $1.3 \pm 0.3$ & $0.8 \pm 0.1$ & $0.9 \pm 0.2$ & $1.4 \pm 0.2$ & $1.0 \pm 0.0$ & $1.1 \pm 0.1$ \\
\hline $02 / 264$ & 0 & 0 & 0 & & & & & & $0.6 \pm 0.1$ & & $1.6 \pm 0.1$ & & \\
\hline $02 / 286$ & 0 & 0 & 0 & $0.3 \pm 0.1$ & $1.7 \pm 0.1$ & $2.6 \pm 0.2$ & $0.9 \pm 0.1$ & $1.1 \pm 0.2$ & $0.8 \pm 0.1$ & $0.9 \pm 0.1$ & $1.8 \pm 0.1$ & $1.0 \pm 0.0$ & $1.2 \pm 0.1$ \\
\hline 301 & 0 & 0 & 0 & $0.1 \pm 0.0$ & $1.8 \pm 0.1$ & $2.2 \pm 0.4$ & $1.7 \pm 0.3$ & $1.5 \pm 0.0$ & $0.5 \pm 0.0$ & $0.8 \pm 0.2$ & $1.7 \pm 0.2$ & $1.0 \pm 0.0$ & $1.3 \pm 0.1$ \\
\hline $02 / 476$ & 0 & 0 & 0 & $0.4 \pm 0.1$ & $1.1 \pm 0.2$ & $2.0 \pm 0.5$ & $1.3 \pm 0.3$ & $1.0 \pm 0.2$ & $0.9 \pm 0.2$ & $1.9 \pm 0.2$ & $1.9 \pm 0.1$ & $1.0 \pm 0.0$ & $1.3 \pm 0.1$ \\
\hline $02 / 278$ & 0 & 0 & 0 & $0.3 \pm 0.1$ & $1.5 \pm 0.3$ & $2.5 \pm 0.5$ & $1.0 \pm 0.0$ & $1.3 \pm 0.1$ & $0.9 \pm 0.1$ & $1.5 \pm 0.3$ & $1.6 \pm 0.1$ & $1.3 \pm 0.3$ & $1.3 \pm 0.1$ \\
\hline $00 / 274$ & 0 & 0 & 0 & $0.4 \pm 0.1$ & $1.8 \pm 0.1$ & $2.1 \pm 0.4$ & $0.8 \pm 0.1$ & $1.8 \pm 0.3$ & $0.9 \pm 0.1$ & $0.6 \pm 0.1$ & $2.0 \pm 0.0$ & $1.5 \pm 0.3$ & $1.3 \pm 0.1$ \\
\hline $02 / 378$ & 0 & 0 & 0 & $0.6 \pm 0.1$ & $1.5 \pm 0.2$ & $1.8 \pm 0.5$ & $1.4 \pm 0.2$ & $1.7 \pm 01$ & $0.8 \pm 0.1$ & $1.1 \pm 0.2$ & $1.6 \pm 0.1$ & $1.6 \pm 0.2$ & $1.3 \pm 0.1$ \\
\hline $02 / 103$ & 5 & 5 & 10 & $0.3 \pm 0.1$ & $1.9 \pm 0.1$ & $2.3 \pm 0.6$ & $0.9 \pm 0.1$ & $1.6 \pm 0.1$ & $0.5 \pm 0.0$ & $1.1 \pm 0.1$ & $1.5 \pm 0.2$ & $2.3 \pm 0.3$ & $1.4 \pm 0.1$ \\
\hline $02 / 456$ & 0 & 0 & 0 & $0.4 \pm 0.1$ & $1.1 \pm 0.1$ & $2.4 \pm 0.5$ & $1.5 \pm 0.3$ & $1.6 \pm 0.2$ & $0.8 \pm 0.1$ & $1.8 \pm 0.3$ & $2.0 \pm 0.3$ & $1.8 \pm 0.3$ & $1.5 \pm 0.1$ \\
\hline $02 / 455$ & 0 & 0 & 0 & $0.4 \pm 0.1$ & $1.6 \pm 0.1$ & $2.6 \pm 0.6$ & $1.8 \pm 0.3$ & $1.5 \pm 0.2$ & $1.3 \pm 0.3$ & $2.0 \pm 0.2$ & $1.8 \pm 0.3$ & $1.0 \pm 0.0$ & $1.5 \pm 0.1$ \\
\hline $02 / 102$ & 0 & 0 & 5 & $0.6 \pm 0.1$ & $1.9 \pm 0.1$ & $2.6 \pm 0.6$ & $1.3 \pm 0.3$ & $1.8 \pm 0.1$ & $0.8 \pm 0.1$ & $1.9 \pm 0.4$ & $1.9 \pm 0.1$ & $2.5 \pm 0.3$ & $1.7 \pm 0.1$ \\
\hline $02 / 371$ & 0 & 0 & 0 & $0.9 \pm 0.1$ & $2.1 \pm 0.1$ & $3.3 \pm 0.1$ & $2.3 \pm 0.3$ & $2.0 \pm 0.0$ & $1.3 \pm 0.1$ & $1.9 \pm 0.3$ & $2.4 \pm 0.4$ & $2.5 \pm 0.3$ & $2.1 \pm 0.1$ \\
\hline $02 / 40$ & 0 & 0 & 5 & $1.3 \pm 0.2$ & $1.9 \pm 0.1$ & $2.9 \pm 0.3$ & $2.3 \pm 0.3$ & $1.8 \pm 0.1$ & $1.6 \pm 0.2$ & $2.1 \pm 0.2$ & $2.3 \pm 0.1$ & $2.8 \pm 0.3$ & $2.1 \pm 0.1$ \\
\hline $02 / 383$ & 0 & 0 & 0 & $0.9 \pm 0.2$ & $1.8 \pm 0.1$ & $3.4 \pm 0.3$ & $2.0 \pm 0.0$ & $2.5 \pm 0.2$ & $1.3 \pm 0.1$ & $2.5 \pm 0.2$ & $2.1 \pm 0.1$ & $2.8 \pm 0.3$ & $2.1 \pm 0.1$ \\
\hline $98 / 37$ & 9 & 19 & 19 & $1.4 \pm 0.2$ & $2.4 \pm 0.1$ & $3.8 \pm 0.1$ & $3.0 \pm 0.0$ & $2.8 \pm 0.1$ & $2.8 \pm 0.1$ & $2.8 \pm 0.2$ & $3.0 \pm 0.0$ & $3.0 \pm 0.0$ & $2.8 \pm 0.1$ \\
\hline
\end{tabular}


from that of the "MAX 4" clone in the third harvest. Both black poplar reference clones exhibited lower mean values than most of the P. nigra clones from controlled crosses, although significant differences were not found in any of the harvests. Descendants of clone 202 exhibited up to $22 \%$, $34 \%$ and $11 \%$ higher DMIP values than did their parent during the first, second and third harvests, respectively (Tab. S1 in Supplementary material). The DMIPs were very strongly correlated with the TCA in both the second and third harvest $(R=$ $0.877, p<0.001$ and $R=0.918, p<0.001$, respectively).

Similar to the DMIP results, the "MAX 4" clone showed the highest dry matter yield per unit area in all harvests (Fig. 3, Tab. S1 in Supplementary material) because negligible mortality was observed during the trial (Tab. 2). The biomass yields of most black poplar clones were significantly low, only the 5 above mentioned $P$. nigra clones did not differ from the interspecific reference clone in the third harvest. The highest increment of dry matter yields per unit area between the first and second harvest was observed in the "MAX 4" clone (i.e., $\left.6.1 \mathrm{tha}^{-1} \mathrm{yr}^{-1}\right)$, for which the yield of the second harvest increased by approximately $54 \%$ relative to that of the first harvest (Fig. $4)$. In the $P$. nigra clones, the yield increment ranged between 0.3 and $3.8 \mathrm{t} \mathrm{ha}^{-1} \mathrm{yr}^{-1}$, and the yield in the second harvest increased by approximately $32 \%$ on average. In one P. nigra clone (02/378), the yield increased by approximately $62 \%$. However, the yield increment of the black poplar reference clones was below average. The differences in the dry matter yields per unit area between the "MAX 4" clone and the best $P$. nigra clones increased in the second harvest, with the highest-yielding $P$. nigra clones exhibiting dry matter yields per unit area that were approximately $71 \%$ (clone $00 / 274$ ) and $66 \%$ (clone $02 / 455$ - Tab. S1 in Supplementary material) of those of the interspecific reference clone in the first and second harvests, respectively. The dry matter yields per unit area decreased in the third harvest (Fig. 3, Tab. S1). The yields in the third harvest relative to that in the first harvest were equivalent in one clone and even lower in 13 clones. These clones included both reference $P$. nigra clones and the "MAX 4" reference clone, although its yield remained $10 \%$ higher than the best black poplar clone (02/455). The yield decrease between the second and third harvest was significant in 13 clones, with the highest decrease in the most productive "MAX 4" clone (Fig. 4), while the decrease in low-yielding black poplar clones was insignificant (Tab. S1 in Supplementary material). The percentage of yield decrease between the second and third harvest of the "MAX 4" reference clone was significantly higher than that of some high-yielding $P$. nigra clones (Fig. 4).

The average annual production of the "MAX 4" reference clone over three rota-

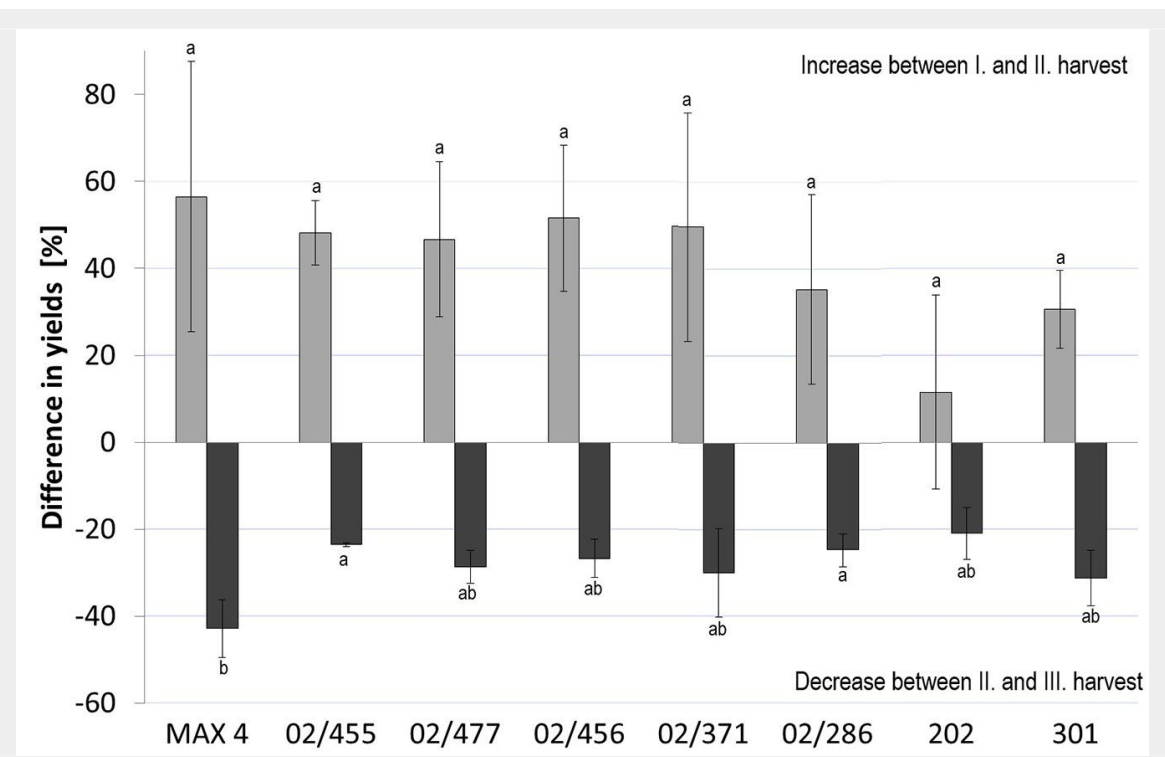

Fig. 4 - Percentage differences in the dry matter yield for the five best $P$. nigra clones from controlled crosses (02/455, 02/477, 02/456, 02/371, 02/286), P. nigra reference clones from natural populations $(202,301)$ and the $P$. nigra $\times P$. maximowiczii reference clone "MAX 4" between subsequent harvests. Different letters are related to the results of multiple comparisons of the mean ranks through a post hoc test. The bars represent the standard errors of the mean values.

tions was $12.8 \mathrm{t} \mathrm{ha}^{-1} \mathrm{yr}^{-1}$, while this value in the black poplar clones ranged between 5.8 and $9.4 \mathrm{t} \mathrm{ha}^{-1} \mathrm{yr}^{-1}$. The black poplar reference clones $(202,301)$ were among the clones with the lowest annual production (Tab. S1 in Supplementary material).

\section{Growth traits}

The growth traits were measured at the end of the vegetation period just before each harvest, and significant differences were observed in all the evaluated traits (Tab. 1, Tab. S2 in Supplementary material),

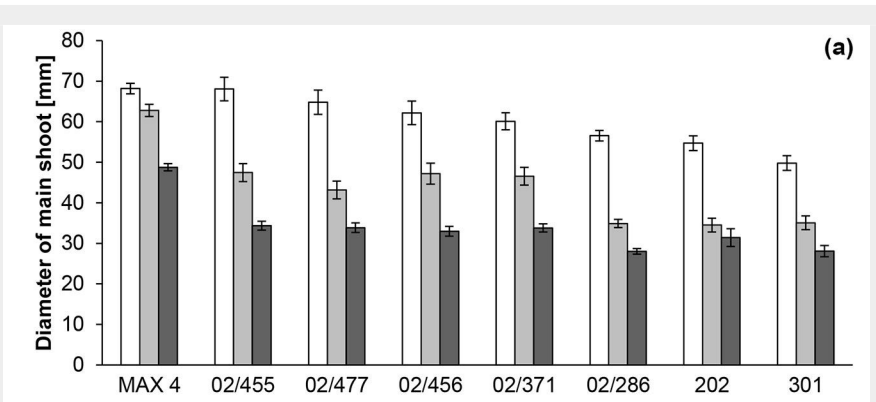

Fig. 5 - Mean value of (a) the main shoot diameter, (b) the number of shoots and (c) the TCA (total crosssectional area) for the five best $P$. nigra clones from controlled crosses (02/455, 02/477,

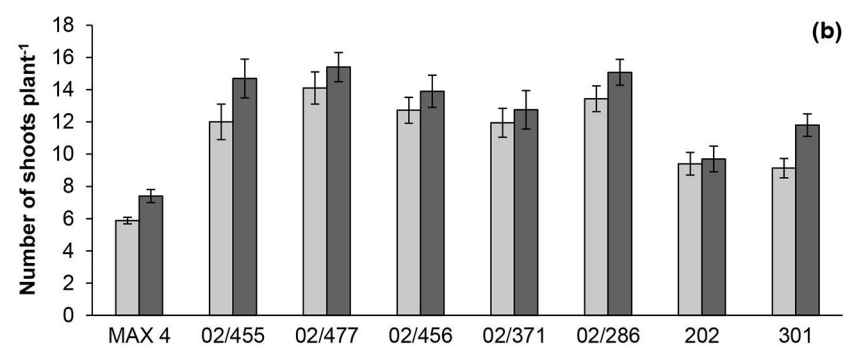

$02 / 456,02 / 371$ 02/286), P. nigra reference clones from natural populations $(202,301)$ and the $P$. nigra $\times$ $P$. maximowiczii reference clone "MAX 4" within the first (I.), sec-

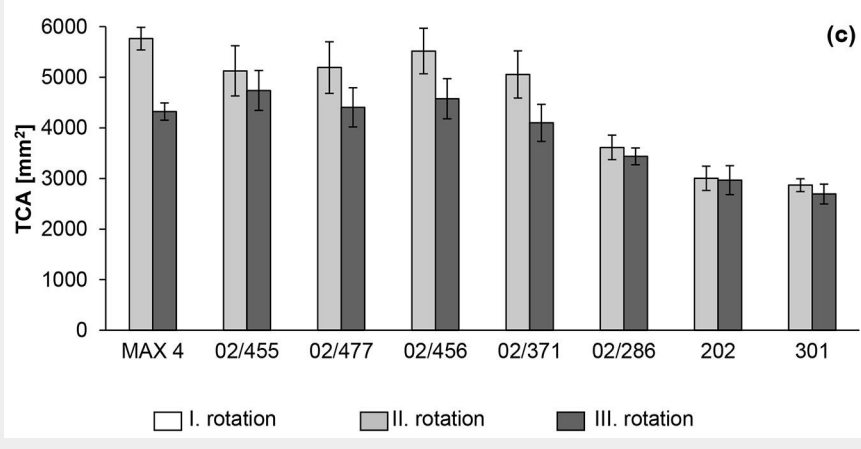


with the independent variable of clone having the greatest effect. A significant block effect was observed only in TCA.

The diameter of the main shoot was the highest in all clones before the first harvest, followed by that before the second and third harvest (Fig. 5a, Tab. S2 in Supplementary material). The "MAX 4 " clone had the greatest mean diameter of the main shoot before all three harvests at 68.2, 62.8 and $48.8 \mathrm{~mm}$, respectively, and it differed significantly from all $P$. nigra clones in the second and third rotation. The best $P$. nigra clones had main shoot diameters of $68.1,47.5$ and $34.7 \mathrm{~mm}$ in the three rotations, respectively, with clone 02/455 showing the best results in the first two rotations and 02/264 showing the best results in the third rotation. Both P. nigra clones selected from nature were among the clones that showed the lowest main shoot diameter in all three rotations. Compared with the parental clone, the descendants of clone 202 exhibited greater shoot diameters during the first, second and third harvests of up to $16 \%, 29 \%$ and $4 \%$, respectively (Tab. S2 in Supplementary material). Similar to the main shoot diameter, higher average shoot diameters were found before the second harvest than the third harvest, and the best diameters in these harvests were found in the "MAX 4" clone, at 30.5 and $24.6 \mathrm{~mm}$, respectively. The average shoot diameter of the $P$. nigra clones ranged between 17.0 and 22.5 in the second rotation and 16.2 and $19.0 \mathrm{~mm}$ in the third harvest (Tab. S2 in Supplementary material). The average shoot diameters of the P. nigra clones were $26 \%$ to $44 \%$ and $23 \%$ to $34 \%$ smaller than that of the "MAX 4" clone before the second and third harvest, respectively.

After the first harvest, the number of shoots per plant increased due to coppicing and varied greatly. The number of shoots was greater in the black poplar clones than in clone "MAX 4" (Fig. 5b, Tab. S2 in Supplementary material) and ranged between 5.9 and 14.2 shoots per plant. The mean number of coppiced shoots in the $P$. nigra clone with the greatest shoot number (02/476) was 2.4 times higher than that of the interspecific reference clone "MAX 4 " just before the second harvest. In the third rotation, the number of shoots in all clones was higher than that in the second rotation, and the lowest number of shoots was observed in the "MAX 4" clone at 7.4, while the highest number was found in clone $02 / 476$ at 16.1 .

Total cross-sectional area (TCA) accounts for the number of shoots and their diameters. In this trial, the TCA values ranged between 2867 and $5764 \mathrm{~mm}^{2}$ before the second harvest and showed high variability, particularly among the tested clones (Fig. $5 \mathrm{C}$, Tab. S2 in Supplementary material). The "MAX 4" clone exhibited the highest TCA value in the second harvest. Before the third harvest, the TCA values were lower in most of the clones than before the second harvest and ranged between 2692 and $4738 \mathrm{~mm}^{2}$ with highest TCA observed in $P$. nigra clone 02/455. Compared with the parental clone, the descendants of clone 202 showed up to $50 \%$ and $31 \%$ higher TCA values during the second and third harvest, respectively, and the lowest values were observed in both black poplar reference clones.

\section{Health status}

Plant mortality was negligible after the establishment of the trial (Tab. 2). Before the first harvest, only one clone (02/103) exhibited $5 \%$ mortality. Before the third harvest, it exhibited 10\% mortality, and two additional clones (02/40, 02/102) exhibited $5 \%$ mortality.

The occurrence of $M$. larici-populina leaf rust was evaluated under field conditions (Tab. 2). The particular dates of rust incidence evaluations were positively correlated with themselves $(R=0.382-0.741, p<$ 0.001). The results show that the rust incidence is strongly dependent on the clone; the Pearson's coefficient of contingency was $C=0.692, p<0.001$.

Although the lowest rust incidence was observed in the "MAX 4" reference clone, some of the individual black poplar clones showed an equally low incidence. The mean point value of leaf rust incidence in the "MAX 4" clone was $0.4 \pm 0.1$ over 9 years, and the mean point values in the black poplar clones showing minimal rust incidence (00/234, 02/477 and 202) were between $0.7 \pm 0.1$ and $1.0 \pm 0.1$. In contrast, the clones showing the poorest results for this parameter were 02/383,02/371, and $02 / 40$, with mean point values $2.1 \pm 0.1$. The susceptible clone $98 / 37$ showed the highest values of rust incidence over all 9 years with a mean point value of $2.8 \pm 0.1$.

In the year with the highest rust incidence (2011), the mean point values for most of the clones with the highest resistance did not exceed 2 points, while the clones that showed the highest rust incidence had 3 or more points. The susceptible clone $98 / 37$ received 3.8 points.

\section{Discussion}

The performance of 19 P. nigra clones originating from intraspecific crossings were compared to that of 2 clones from natural populations and the interspecific clone "MAX 4" in SRC systems over three three-year rotations. The $P$. nigra clones used in the current study are the result of more than 20 years of breeding, the goal of which was to obtain genotypes suitable for biomass production that could replace interspecific Populus hybrids threatening autochthonous $P$. nigra species through gene introgression (Heinze 1997, Benetka et al. 2002b, Vanden Broeck et al. 2005, Smulders et al. 2008). The other goal was to obtain clones resistant to existing virulences of $M$. larici-populina in the Czech Republic, in which the resistance would be stable, as expected in P. nigra (Legionnet et al. 1999,
Dowkiw et al. 2012). The first step was the selection of natural $P$. nigra populations to obtain plant material with high genetic diversity, and extensive crossing of geographically different genotypes generated intraspecific hybrid populations, from which the selection was made (Benetka et al. 2012). The current study focused on the selection of clones with favourable biomass production, higher $M$. larici-populina resistance and drought tolerance. Compared with the previous research of Bastien et al. (2014), the selection was performed based on field evaluations, without the use of molecular markers and laboratory evaluations of rust resistance.

\section{Biomass production}

In this study, the P. nigra clones from controlled crosses showed higher growth and yield parameter values than did the clones selected from natural populations that had previously been confirmed to be suitable for SRC plantations (Benetka et al. 2014, Štochlová et al. 2019). The best intraspecific descendants of clone 202 displayed up to $34 \%$ greater dry matter yield per unit area and up to $29 \%$ greater shoot diameter for the main shoots compared with their parent during the second harvest. In $P$. $\times$ canadensis, Dillen et al. (2009) obtained an increase of $26.5 \%$ in the 2-year-old shoot diameter, and Marron \& Ceulemans (2006) reported an increase of $23.3 \%$. These results cannot be compared due to the different study conditions involved, although the observed increases are satisfactory from a breeding perspective.

Higher growth parameter values of the tested $P$. nigra clones in comparison with clones used in Štochlová et al. (2015) were achieved under the same rust disease attack, thereby excluding different effects of the pathogen and confirming that breeding progress has been achieved through intraspecific hybridization. The lower values obtained for clones from natural populations could be affected by the water regime at the locality, which is characterized by lower ground water levels and precipitation, potentially revealing drought tolerance in the best $P$. nigra clones from controlled crosses.

In this study, many black poplar clones were evaluated, although the presented data were obtained in small plots at only one locality. However, a similar trial with the same clones has been established by the Central Institute for Supervising and Testing in Agriculture at Stachy, Czech Republic (South Bohemia - 49 $06^{\prime} 06^{\prime \prime} \mathrm{N}, 13^{\circ}$ $39^{\prime} 60^{\prime \prime} \mathrm{E}$ ) in 2010. The plantation site is located at an altitude of $742 \mathrm{~m}$ a.s.l. and slopes slightly towards the northeast, and it was used as pasture land before the establishment of the plantation. The soil is dystric Cambisol on paragneiss with a $\mathrm{pH}$ from 6.2-6.5. The average annual temperature is $6.4{ }^{\circ} \mathrm{C}$ (in growing period $14.2{ }^{\circ} \mathrm{C}$ ), and the average cumulative precipitation is $742 \mathrm{~mm}$ (growing period $378 \mathrm{~mm}$ ). The 
plantation was harvested for the first time in autumn 2015. A significant strong correlation $(R=0.666, p=0.001)$ was found between rank of clones according to the yields at Stachy and the average annual dry matter production in Průhonice. Among the best-performing clones under marginal growing conditions were clones 02/456, 02/455 and 02/383 (Reininger et al. 2015); therefore, two of the three best clones from both trials are the same, thus confirming their high adaptability. However, clones with a distinct rank were observed in this study, including clones 02/383 and 301, which may be less sensitive to marginal growing conditions and lower temperatures (at Stachy) and present much better growth than that observed in the current trial (at Prühonice). In contrast, clone 02/477 belonged to the clones with a low yield under marginal growing conditions; therefore, this clone likely requires better growing conditions. Nevertheless, further evaluations of the best clones must be made via field tests using larger plots in more localities to determine the genotype $x$ site interactions of the clones.

The interspecific clone "MAX 4" performed better for most of the evaluated traits. The species combination giving rise to the "MAX 4" clone appears to be very efficient compared with other interspecific combinations (Zamora et al. 2013). Observed differences in evaluated traits can be important for selection of right harvesting method and rotation length (optimal diameter of main shoots for mechanical harvesting), wood assortment and its utilization (chips, logs, pulp, etc. - Marron et al. 2012). Also differences in growth and yield traits can affect wood properties as higher number of shoots in P. nigra clones could lead to a higher proportion of bark and therefore differences in combustion heat (Geyer et al. 2000, Benetka et al. 2002a).

The biomass production of new $P$. nigra clones coming from controlled crosses was higher than production of clones from natural population in the study by Benetka et al. (2014) with exception of the third harvest of certain clones grown in optimal or marginal conditions. This difference could be explained by different growing conditions, the lower amount of precipitation in the third rotation, and different spacing.

The intraspecific hybridization success is evident compared to the results of other studies in which black poplar clones were also used (Dillen et al. 2013, Benetka et al. 2014, Nielsen et al. 2014, Verlinden et al. 2015). However, different growing conditions, spacing and management were implemented, and the best black poplar clones showed mostly comparable or even higher biomass yields.

\section{Rust resistance}

In a previous work by Štochlová et al. (2015), a negative correlation was demonstrated between the shoot thickness, which depends on the amount of nutrient storage, and the incidence of $M$. larici-populina. The decrease in the growth rate of plants with rust incidence from 1 to 2.25 points (using the same point evaluation) was not important, and the higher rust incidence in plants from the end of August did not negatively affect the shoot thickness (amount of nutrient storage - Štochlová et al. 2015). These findings indicate that the incomplete rust resistance observed in certain P. nigra clones is sufficient to defend against the decrease in biomass yield caused by rust. In the current trial, a lower rust incidence in comparison with that in the study of Štochlová et al. (2015) was observed in 2009 and 2010, although the trials were situated very close to each other. In 2011, the rust incidence in both trials was comparable (resistant clones 97/152 and 97/157 were evaluated as 2.25 points and susceptible clone as 4.33 points). This difference could be explained mainly due to the use of different clones, with a low number of susceptible clones in the current study and a looser spacing. According to several years of field observations, the stability of the higher rust resistance was confirmed in the best clones. These clones were even better than clones with higher levels of rust resistance identified in a previous work (Štochlová et al. 2015). However, a high variability in leaf rust susceptibility was observed among the tested clones, which supports the notion of resistance based on several quantitative trait loci (Legionnet et al. 1999, Benetka et al. 2005, Štochlová et al. 2015). Intraspecific clones with a high level of resistance were identified, which are important for followup resistance breeding programmes because rust-resistant clones could achieve higher biomass production (Dillen et al. 2013, Štochlová et al. 2015). Moreover, P. nigra is one of the parents of most of the most commonly grown poplar clones; therefore, the best $P$. nigra clones could be used for other interspecific crosses.

\section{Drought tolerance}

Both low amounts of precipitation and high temperatures characterized by a low Lang's rain factor during the third rotation (Fig. 2) enabled the evaluation of the drought resistance in the trialled clones, although the trial was not established with this goal. The biomass yield of the black poplar clones and "MAX 4" in the present study decreased in the third harvest in comparison with that in the second harvest. This is in contrast to the results obtained at the Rosice site (Benetka et al. 2014), in which a similar spacing was used and the biomass yield was the same or higher in the third or fourth harvest than in the second harvest. The observed decrease in Průhonice in the present study was caused by drought, whereas at the Rosice site, the soil was always sufficiently supplied with groundwater coming from a nearby river, and therefore, plant growth was not dependent on the amount of precipitation (Benetka et al. 2014). An increasing yield in the third or fourth rotation was also confirmed in other experiments in some clones (Al Afas et al. 2008, Dillen et al. 2013).

As a result of the drought, the yield decrease between second and third harvest was the highest and was significant in the most productive "MAX 4" clone, while the decrease in low-yielding black poplar clones was non-significant. The same response was achieved even in poplar genotypes originating from $P$. deltoides and $P$. trichocarpa (Monclus et al. 2009). In contrast, the yield decrease of some high-yielding black poplar clones was significantly lower than that of the "MAX 4" clone, indicating their higher drought tolerance compared with "MAX 4" clone. It will be very interesting to observe the biomass yield tendency and differences among intraspecific black poplar clones and reference clones in a series of years with continuous low Lang's rain factors.

\section{Prospects and utilization}

The current study indicates a high potential for further intraspecific $P$. nigra breeding. Obtaining clones that are relatively highly resistant to $M$. larici-populina is highly valuable and can disprove the notion of the unsuitability of $P$. nigra in SRC cultures due to its susceptibility to this pathogen.

In particular, pure $P$. nigra and $P$. trichocarpa clones appeared to be most suitable for growth under suboptimal conditions (i.e., planted on degraded land - Dillen et al. 2013), which meets the requirements for growing SRC cultures in areas that are not suitable for intensive agricultural production.

\section{Conclusions}

In the present study, the significance of natural populations (subpopulations) as a source of genetic diversity for further P. nigra breeding was confirmed. It was shown that the first generation of controlled, intraspecific cross-pollination among selected clones of $P$. nigra was effective and convenient for breeding with the goals of high biomass yields and resistance to $M$. larici-populina. It was shown that $P$. nigra can be a genetic source of durable resistance to this pathogen.

Most $P$. nigra clones from controlled crosses exhibited higher values of all evaluated traits than those of clones selected from natural populations. Three high-yielding clones (02/455, 02/477 and 02/456) that were highly resistant to leaf rust and had higher drought tolerance were selected and can be recommended for growth in SRC cultures mainly in specific areas. Further intraspecific breeding of $P$. nigra has considerable potential, although the interspecific clone "MAX 4" performed better than did most of the $P$. nigra clones. The $P$. nigra clones presented herein will be used in further intraspecific breeding cycles with 
the goal of further yield increases. The possibility of transferring relatively durable resistance towards $M$. larici-populina to interspecific hybrids must be verified.

\section{Acknowledgements}

The authors gratefully acknowledge D. Reininger from the Central Institute for Supervising and Testing in Agriculture (Brno, (zech Republic) for detailed locality descriptions of their trial, the assistance of K. R. Edwards and American Journal Experts for improving the English language of the manuscript, as well as the anonymous reviewers for their comments on previous versions of the manuscript.

This research was funded by institutional support (VUKOZ-IP-00027073). This contribution fits within the COST Action FP 1301 "EuroCoppice" of the EU Framework Programme Horizon 2020.

\section{References}

Al Afas N, Marron N, Van Dongen S, Laureysens I, Ceulemans R (2008). Dynamics of biomass production in a poplar coppice culture over three rotations (11 years). Forest Ecology and Management 255: 1883-1891. - doi: 10.1016/j.for eco.2007.12.010

Anděl J (1998). Statistické metody [Statistical methods]. Matfyzpress, Prague, Czech Republic, pp. 274. [in Czech].

Bastien C, El Malki R, Dowkiw A, Faivre-Rampant P, Albert E, Villar M, Poursat P, Almeida J, Ridel $C$, Guérin V, Viguier B, Steenackers $M$, Jorge V (2014). Exploration of Populus nigra L. genetic variation for partial resistance against the coadapted pathogen Melampsora larici-populina. In: "International Poplar Symposium (IPS-VI)" (Johnson AM ed). Vancouver (BC, Canada), 2023 July 2014, pp. 98. [online] URL: http://agris. fao.org/agris-search/search.do?recordID=LV2O 16029475

Bates D, Mächler M, Bolker B, Walker S (2015). Fitting linear mixed-effects models using Ime4. Journal of Statistical Software 67: 1-48. - doi: 10.18637/jss.v067.io1

Benetka V, Bartáková I, Mottl J (2002a). Productivity of Populus nigra L. ssp. nigra under shortrotation culture in marginal areas. Biomass and Bioenergy 23: 327-336. - doi: 10.1016/So961-9534 (02)00065-X

Benetka V, Vacková K, Bartáková I, Pospíšková M, Rasl M (2002b). Introgression in black poplar (Populus nigra L. ssp. nigra) and its transmission. Journal of Forest Science 48: 115-120. - doi: 10.17221/11863-JFS

Benetka V, Šálková I, Vrátny F (2005). Selection of clones of Populus nigra L. ssp. nigra for resistance to Melampsora larici-populina Kleb. Rust. Journal of Forest Science 51: 161-167. - doi: 10.17221/45 55-JFS

Benetka V, Vrátny F, Šálková I (2007). Comparison of the productivity of Populus nigra L. with an interspecific hybrid in a short rotation coppice in marginal areas. Biomass and Bioenergy 31: 367-374. - doi: 10.1016/j.biombioe.2007.01.0 05

Benetka V, Novotná K, Štochlová P (2012). Wild populations as a source of germplasm for black poplar (Populus nigra L.) breeding program- mes. Tree Genetics and Genomes 8: 1073-1084. doi: 10.1007/ S11295-012-0487-6

Benetka V, Novotná K, Štochlová P (2014). Biomass production of Populus nigra L. clones grown in short rotation coppice systems in three different environments over four rotations. iForest 7: 233-239. - doi: 10.3832/ifor1162007

Bentsen NS, Felby C (2012). Biomass for energy in the European Union a review of bioenergy resource assessments. Biotechnology for Biofuels 5: 25. - doi: 10.1186/1754-6834-5-25

Braatne JH, Hinckley TM, Stettler RF (1992). Influence of soil water on the physiological and morphological components of plant water balance in Populus trichocarpa, Populus deltoides and their F1 hybrids. Tree Physiology 11: 325339. - doi: 10.1093/treephys/11.4.325

DEFRA (2004). Growing short rotation coppice. Best Practice Guidelines for Applicants to Defra's Energy Crops Scheme. Department for Environment, Food and Rural Affairs - DEFRA, London, UK, pp. 32.

Dillen SY, Storme V, Marron N, Bastien C, Neyrinck $S$, Steenackers $M$, Ceulemans R, Boerjan $\mathrm{W}$ (2009). Genomic regions involved in productivity of two interspecific poplar families in Europe. 1. Stem height, circumference and volume. Tree Genetics and Genomes 5: 147-164. doi: 10.1007/s11295-008-0175-8

Dillen SY, Djomo SN, Al Afas N, Vanbeveren S, Ceulemans R (2013). Biomass yield and energy balance of a short-rotation poplar coppice with multiple clones on degraded land during 16 years. Biomass and Bioenergy 56: 157-165. - doi: 10.1016/j.biombioe.2013.04.019

Dowkiw A, Bastien C (2004). Characterization of two major genetic factors controlling quantitative resistance to Melampsora larici-populina leaf rust in hybrid poplars: strain specificity, field expression, combined effects, and relationship with a defeated qualitative resistance gene. Phytopathology 94: 1358-1367. - doi: 10.1094/PHYTO.2004.94.12.1358

Dowkiw A, Jorge V, Villar $M$, Voisin E, Guérin V, Faivre-Rampant $P$, Bresson A, Bitton F, Duplessis S, Frey P, Petre B, Guinet C, Xhaard C, Fabre B, Halkett F, Plomion C, Lalanne C, Bastien C (2012). Breeding poplars with durable resistance to Melampsora larici-populina leaf rust: a multidisciplinary approach to understand and delay pathogen adaptation. In: Proceedings of the " 4 " International Workshop on Genetics of Host-Parasite Interactions in Forestry: Disease and Insect Resistance in Forest Trees" (Sniezko RA, Yanchuk AD, Kliejunas JT, Palmieri KM, Alexander JM, Frankel SJ tech. cords.). Eugene (Oregon, USA), 31 Jul - 5 Aug 2011. General Technical Report PSW-GTR-240, Pacific Southwest Research Station, USDA Forest Service, Albany, CA, USA, pp. 31-38. - doi: 10.2737/PSW-GTR-240

FAO (2016). Poplars and other fast-growing trees - Renewable resources for future green economies. Synthesis of country progress reports. In: Proceedings of the " 25 th Session of the International Poplar Commission". Berlin (Germany) 13-16 Sep 2016. Working Paper IPC/ 15, Forestry Policy and Resources Division, FAO, Rome, Italy, pp. 106.

Frey P, Gérard P, Feau N, Husson C, Pinon J
(2005). Variability and population biology of Melampsora rusts on poplars. In: "Rust Diseases of Willow and Poplar" (Pei MH, McCracken $A R$ eds). CAB International, Wallingford, UK, pp. 63-72. - doi: 10.1079/97808519999 99.0063

Gastine F, Berthelot A, Bouvet A, Servant H, Roy $B$ (2003). La protection phytosanitaire du cultivar "Beaupré" - est-elle efficace? [Plant protection of the cultivar "Beaupré" - is it effective?]. Informations Forêt 2, pp. 6. [in French]

Geyer WA, DeWyke J, Walawender WP (2000). Biomass and gasification properties of young Populus clones. Wood and Fiber Science 32: 375-384. [online] URL: http://wfs.swst.org/in dex.php/wfs/article/view/413

Heinze B (1997). A PCR marker for a Populus deltoides allele and its use in studying introgression with native European Populus nigra. Belgian Journal of Botany 129: 123-130. [online] URL: http://www.jstor.org/stable/20794389

Herve C, Ceulemans R (1996). Short-rotation coppiced vs non-coppiced poplar: a comparative study at two different field sites. Biomass and Bioenergy 11: 139-150. - doi: 10.1016/09619534(96)00028-1

IPC (2000). Directory of poplar and willow experts. Register of Populus L. cultivars. Instituto di Sperimentazione per la Pioppicultura, Casale Monferrato, FAO, Rome, Italy. [CD-ROM]

Jones T, Mclvor I, McManus M (2016). Drought tolerance and water-use efficiency of five hybrid poplar clones. In: "Integrated nutrient and water management for sustainable farming" (Currie LD, Singh R eds). Occasional Report No. 29, Fertilizer and Lime Research Centre, Massey University, Palmerston North, New Zealand, pp. 1-13. [online] URL: http://flrc.massey.ac.nz/ publications.html

Kreuzwieser J, Gessler A (2010). Global climate change and tree nutrition: influence of water availability. Tree Physiology 30: 1221-1234. - doi: 10.1093/treephys/tpq055

Langeveld H, Quist-Wessel F, Dimitriou I, Aronsson P, Baum C, Schulz U, Bolte A, Baum S, Köhn J, Weih M, Gruss H, Leinweber P, Lamersdorf N, Schmidt-Walter P, Berndes G (2012). Assessing environmental impact of short rotation coppice (SRC) expansion: model definition and preliminary results. Bioenergy Research 5: 621-635. doi: 10.1007/s12155-012-9235-x

Legionnet A, Muranty H, Lefèvre F (1999). Genetic variation of the riparian pioneer tree species Populus nigra. II. Variation in susceptibility to the foliar rust Melampsora larici-populina. Heredity 82: 318-327. - doi: 10.1038/sj.hdy.688 4880

Marron N, Villar M, Dreyer E, Delay D, Boudouresque E, Petit J-M, Delmotte FM, Guehl J-M, Brignolas $F$ (2005). Diversity of leaf traits related to productivity in 31 Populus deltoides $x$ Populus nigra clones. Tree Physiology 25: 425435. - doi: 10.1093/treephys/25.4.425

Marron N, Ceulemans R (2006). Genetic variation of leaf traits related to productivity in a Populus deltoides $\times$ Populus nigra family. Canadian Journal of Forest Research 36: 390-400. doi: 10.1139/X05-245

Marron N, Beimgraben T, Bes de Berc L, Brodbeck F, Eltrop L, Focke J, Haid S, Hardtlein M, Nahm M, Pelz S, Sauter UH, Van Den Kerchove 
L, Weinreich A (2012). Cost reduction and efficiency improvement of Short Rotation Coppice. Technical guide, CREFF Final Report Project ERA-Net Bioenergy CREFF, INRA, France, pp. 159. [online] URL: http://www6. inrae.fr/creff_eng/Project-outputs/Reports-gui des-and-recom mandations-from-CREFF

McDonald B (2010). How can we achieve durable disease resistance in agricultural ecosystems? New Phytologist 185: 3-5. - doi: 10.1111/j.1469-813 7.2009.03108.x

Ministry of Agriculture of the Czech Republic (2018). Výmera RRD dle LPIS - historie, kraje, okresy [Area of SRC by LPIS - history, regions, districts]. eAGRI, Ministry of Agriculture of the Czech Republic, Prague, Czech Republic, web site. [in Czech] [online] URL: http://eagri.cz/pu blic/web/mze/zivotni-prostredi/obnovitelnezdroje-energie/statistiky/vymera-rrd-dle-lpishistorie-kraje.html

Ministry of the Environment of the Czech Republic (1992). Act no. 114/1992 on the Conservation of Nature and Landscape. Official translation, Czech Republic, pp. 56. [online] URL: http:// extwprlegs1.fao.org/docs/pdf/cze4729E.pdf

Minář M (1948). Deštové faktory ČSR [Rain factors of Czechoslovakia]. Státní meteorologický ústav, Prague, Czech Republic, pp. 49. [in Czech]

Monclus R, Dreyer E, Delmotte FM, Villar M, Delay $D$, Boudouresque E, Petit J-M, Marron N, Bréchet C, Brignolas F (2005). Productivity, leaf traits and carbon isotope discrimination in 29 Populus deltoides $\times$ P. nigra clones. New Phytologist 167: 53-62. - doi: 10.1111/j.1469-8137.2005. 01407.x

Monclus R, Dreyer E, Villar M, Delmotte FM, Delay D, Petit J-M, Barbaroux C, Le Thiec D, Bréchet C, Brignolas F (2006). Impact of drought on productivity and water use efficiency in 29 genotypes of Populus deltoides $\times$ Populus nigra. New Phytologist 169: 765-777. - doi: 10.1111/j. 1469-8137.2005.01630.x

Monclus R, Villar M, Barbaroux C, Bastien C, Fichot R, Delmotte FM, Delay D, Petit J-M, Bréchet C, Dreyer E, Brignolas F (2009). Productivity, water-use efficiency and tolerance to moderate water deficit correlate in 33 poplar genotypes from a Populus deltoides $\times$ Populus trichocarpa F1 progeny. Tree Physiology 29: 13291339. - doi: 10.1093/treephys/tppo75

Navarro A, Portillo-Estrada M, Arriga N, Vanbeveren SPP, Ceulemans R (2018). Genotypic variation in transpiration of coppiced poplar during the third rotation of a short-rotation bio-energy culture. Global Change Biology Bioenergy 10: 592-607. - doi: 10.1111/gcbb.12526
Nielsen UB, Madsen P, Hansen JK, Nord-Larsen $T$, Nielsen AT (2014). Production potential of 36 poplar clones grown at medium length rotation in Denmark. Biomass and Bioenergy 64: 99-109. - doi: 10.1016/j.biombioe.2014.03.030

Pinon J (1992). Variability in the genus Populus in sensitivity to Melampsora rusts. Silvae Genetica 41: 25-34. [online] URL: http://www.cabdirect. org/cabdirect/abstract/19921630186

R Core Team (2019). R: A language and environment for statistical computing. R Foundation for Statistical Computing, Vienna, Austria. [online] URL: http://www.R-project.org/

Reininger D, Fiala P, Samek T (2015). Zpráva o testu dřevin na pozemku ve Stachách na Šumavě. Průběžná zpráva [Report of the tree testing at the locality Stachy in the Šumava Mountain. Annual report]. Ústřední kontrolní a zkušební ústav zemědělský, Brno, Czech Republic, pp. 16. [in Czech] [online] URL: http:// eagri.cz/public/web/file/579870/Prub_zprava_2 015.pdf

Schär C, Vidale PL, Lüthi D, Frei C, Häberli C, Liniger MA, Appenzeller C (2004). The role of increasing temperature variability in European summer heatwaves. Nature 427: 332-336. - doi: 10.1038/nature02300

Seneviratne SI, Lüthi D, Litschi M, Schär C (2006). Land-atmosphere coupling and climate change in Europe. Nature 443: 205-209. - doi: 10.1038/nature05095

Smulders MJM, Beringen R, Volosyanchuk R, Vanden Broeck A, Van Der Schoot J, Arens P, Vosman B (2008). Natural hybridisation between Populus nigra L. and P. $\times$ canadensis Moench. Hybrid offspring competes for niches along the Rhine river in the Netherlands. Tree Genetics and Genomes 4: 663-675. - doi: 10.100 7/s11295-008-0141-5

Stanton BJ, Neale DB, Li S (2010). Populus breeding: from the classical to the genomic approach. In: "Genetics and Genomics of Populus" (Jansson S, Bhalerao RP, Groover AT eds). Series "Plant Genetics and Genomics: Crops and Models" vol. 8, Springer-Verlag, New York, USA, pp. 309-348. - doi: 10.1007/978-1-4419-15412 14

Steenackers V (1972). Breeding poplars resistant to various diseases. In: "Biology of Rust Resistance in Forest Trees" (Bingham RT et al. eds). Miscellaneous Publications no. 1221, USDA Forest Service, Washington, DC, USA, pp. 599-607. Štícha V, Macků J, Nuhlíček O (2016). Effect of permanent waterlogging on the growth of poplar clones MAX 4, MAX 5 (J-104, J-105) (Populus maximowiczii A. Henry $\times P$. nigra Linnaeus) and evaluation of wood moisture content in different stem parts - Short Communication. Journal of Forest Science 62: 186-190. - doi: 10.17221/90/2015-JFS

Štochlová P, Novotná K, Benetka V (2015). Variation in resistance to the rust fungus Melampsora larici-populina Kleb. in Populus nigra L. in the Czech Republic. iforest 9: 146-153. - doi: 10.3832/ifor1458-008

Štochlová $\mathrm{P}$, Novotná $\mathrm{K}$, Costa $\mathrm{M}$, Rodrigues $\mathrm{A}$ (2019). Biomass production of poplar short rotation coppice over five and six rotations and its aptitude as a fuel. Biomass and Bioenergy 122: 183-192. - doi: 10.1016/j.biombioe.2019.01.011 Vanden Broeck A (2003). EUFORGEN Technical guidelines for genetic conservation and use for European black poplar (Populus nigra). International Plant Genetic Resources Institute, Rome, Italy, pp. 6.

Vanden Broeck A, Villar M, Van Bockstaele E, VanSlycken J (2005). Natural hybridization between cultivated poplars and their wild relatives: evidence and consequences for native poplar populations. Annals of Forest Science 62: 601-613. - doi: 10.1051/forest:2005072

Verlinden MS, Broeckx LS, Ceulemans R (2015). First vs. second rotation of a poplar short rotation coppice: above-ground biomass productivity and shoot dynamics. Biomass and Bioenergy 73: 174-185. - doi: 10.1016/j.biombioe.2014.12.012 Verwijst T (2001). Willows: an underestimated resource for environment and society. Forestry Chronicle 77: 281-285. - doi: 10.5558/tfC77281-2

Viger M, Smith HK, Cohen D, Dewoody J, Trewin H, Steenackers M, Bastien C, Taylor G (2016). Adaptive mechanisms and genomic plasticity for drought tolerance identified in European black poplar (Populus nigra L.). Tree Physiology 36: 909-928. - doi: 10.1093/treephys/tpw017 Zamora DS, Wyatt GJ, Apostol KG, Tschirner U (2013). Biomass yield, energy values, and chemical composition of hybrid poplars in short rotation woody crop production and native perennial grasses in Minnesota, USA. Biomass and Bioenergy 49: 222-230. - doi: 10.1016/j.biombioe. 2012.12.031

\section{Supplementary Material}

Tab. S1 - Yield parameters of the tested clones in the first (I.), second (II.) and third (III.) harvests.

Tab. S2 - Comparison of the growth parameters.

Link: Novotna_3171@supploo1.pdf 